\title{
The European Tourist Perception Concerning the Jordanian
}

\section{Touristic Package}

\author{
Dr. Marzouq Ayed Al Qeed (Coressponding authour) \\ Faculty of Economics and Administrative sciences, Applied Science Private University \\ P.o.Box 166, Amman 11931, Jordan \\ E-mail: dr_marzouq@yahoo.com \\ Dr. Osamah Al Shihabi \\ Alsra university, Amman, Jordan \\ Dr. Abdelbaset Hasoneh \\ Alsra university, Amman, Jordan \\ Dr. Atef Saleh Aladwan \\ Alplqa applied university, Amman, Jordan
}

\begin{abstract}
This Research aims at identifying the real image of European tourists of the Jordanian tourism Product; investigating the obstacles facing the Jordanian tourism and explore the promotional measures that advance the best use of the available resources. The methodology follows a descriptive and analytical approach (One sample mean t-test, Two independent sample means test and variance analysis) (ANOVA). However, the approach is based upon selecting convenience random sample of 350 Tourists primarily due to limited available time and close financial circumstances of researcher. Guests' perception and reactions to quality standards are considered. The research findings show that the European tourist places a high value on the human aspect of tourism. The Research recommends that authorized personnel of the tourism industry must adopt effective policies and programs to the weak areas and activities of the industries and to improve the employee attitude. The pursuance of effective marketing tourism strategies in Jordan was also recommended. Based upon the findings of research the following conclusions were reached:-
\end{abstract}

The research indicated the importance of improving the quality and number of tourism labor.

A consolidated team of local and international tourism and marketing experts must hold several meetings and concessions in order to pinpoint the blue planning draft of the national tourism Jordanian plan for the short, middle and long term for the purpose of improving the tourism sector as a whole. Highly-acknowledged, experienced and high ranking individuals must demand the present Government to increase the budget mainly to develop a better tourism Infrastructure and superstructure as well as better tourism promotional Campaigns all over Europe. Standards, code of practice and ethics, relevant polices must be established by the authorized ministry, to define issues concerned with prices, services quality control and assurance. Consolidated, profound attention should be directed toward proper use of this strategic, potential source of revenue and strong efforts must be focused to enhance Jordanian tourism. Corporations operating in tourism sector must work toward enhancing the operations and promotion efforts for the sake of the nation as a whole.

Keywords: Image, Perception, Tourism, Physical evidence, Service, Process, Productivity and quality

\section{Introduction}

According to the International Institute for Environment and Development (2001), tourism is one of the largest industries in the world, generating about $11 \%$ of global Gross Domestic Product, employing 200 million people, and transporting nearly 700 million international traveler per year which might double by 2020.Developing countries have only a relatively small share of international tourism market $(30 \%)$, with the rate of foreign tourists growing at $5 \%$ per year, compared with $4.6 \%$ worldwide, besides, this sector contributes effectively to 
the areas of foreign exchange earnings, employment and (Gross Domestic Products). According to the World Tourism Organization, the Arab region accounted for $2.8 \%$ of total worldwide arrivals, and just below $2.6 \%$ of worldwide receipts in 1999. This is a small improvement on the figures reported in 1998. Oman, Lebanon and Jordan showed the strongest growth in visitors arrival, concerning Jordan; tourists arrivals in 1999 totaled $1,357,822$ compared with $1,256,428$ in 1998 . Tourists from European countries accounted for $21.6 \%$ of total tourists' arrivals in 1999,. According to the Central Bank of Jordan, tourists receipts in 1999 amounted to 587 Million JD ( $\$ 828$ Million US) compared with 562 Million JD (\$792 Million US) in 1998. The contribution of tourism to the Jordanian Gross Domestic Product in 1999 stood at 9.9\%. By the end of 2001, the contribution rose to $9 \%$. It is interesting to know that tourists contribution to export increased from $40.9 \%$ in 1994 to $43.4 \%$ in 1999 - an indication of the significance of Jordanian tourism industry for the economy of the Kingdom (Ministry of Tourism Statistical Department, Amman, 1994/2000).

According to a study published by World Tourism Organization on competition in international tourism, tourism and travel industry are strongly globalized. There are still certain problems facing developed and developing countries regarding competition, essential facilities control and computer reservation system. To face such competition in an effective manner, tourism authorities should have accurate market definition and market structure; hence, competition among nations to attract more foreign tourism should be taken into account when designing tourism campaign at national level (WTO: 2001). A study conducted by a team of experts in the field of tourism in Jordan (Vocational Training Corporation 2000 / Jordan Committee for Economical Development 1999) shows that the Jordanian tourism industry is in dire need for:

Adopting a new tourism culture based on a thorough understanding of the nature of tourism supply and demand in the country, and on a better appreciation of the benefits and values sought by foreign tourists. Reengineering Jordanian hotel management (in terms of philosophy and practices) in order to adapt to newly emerging trends, perceptions, directions and attitudes dictated by the new tourism environment in the region and worldwide. An initiating applied creative programs in human resource management and international marketing tourism (Economic Indicators, 1999).

\section{Tourism Development: Overview}

A foreign tourist, according to the League of Nations is person visiting a country, for a period of time not less 24 hours. This definition if a tourist also includes in the visuals traveling for pleasure, domestic reasons, for healthcare, education etc. (World Tourism Organization, 1992). The concept of a tourist also includes traveling to meetings for scientific, administrative, diplomatic, religious, athletic, etc. Moreover, the above-mentioned definition also covers persons arriving in the course of sea cruise even if they spend less than 24 hours. Tourism is often accompanied by cultural exchange and cultural enrichment of those who travel as well as those at the receiving ends. Cultural factors attract tourists to destination, architecture, historical monuments and birthplaces of the famous places most visited by tourists (Burkart \& Medlik: 1985). Consumer Travel Industry includes the travel product as a service produced and consumed at the same time. Consumer rights of travel, products and services have the same rise and protection as consumers of other products sold in the business world. While most legislations and regulations are created mainly for other industries and are quite broad, it has some applicability to travel industry. This is particularly true in the advertising area. The tourism package tour has grown in the last thirty years into a sizable industry. In the USA alone, more than 18.7 million Americans bought package tours in 1999 spending over $\$ 4$ billion. In 2000, the amount spent on package tours in the U. S. A exceeded $\$ 9.8$ billion.

\section{Formal Tourism Sector in Jordan}

Tourism institutions in Jordan include the following (Royal Scientific Society: 2000): -

Ministry of Tourism and Antiquities which is the official authority in charge of tourism in Jordan. It is responsible for the improvement and preservation of tourist resources as well as marketing Jordan abroad. Jordan Tourism Board (Old Title; Tourism Promotion Corporation; TBC): it has been recently established to cope with the development of the tourism sector in the country and to institutionalize tourism promotion and development activities. Travel Agencies Association, which works on marketing Jordan historical sites and recreational places and facilities. It offers integrated programs for the tourists during their visit to Jordan. International Hotel Association, which offers integrated programs for group tourism from all over the world, using up-to-date marketing techniques, including the Internet. Royal Jordanian Airline offices and Agencies; which plays a vital role in promoting Jordan in the world of tourism by adopting their own marketing plans and programs. Marketing strategy of tourism in Jordan includes the following elements: human resources, financing, information system, and tourism constituents. Human resources aim at upgrading the level of labor force in the tourism sector, in addition to the participation of the local community in developing the touristic sites. The 
policies of tourism in Jordan go around the establishment of specialized institutes, conducting specialized training courses, the introduction of tourism marketing topics at high schools, holding workshops and seminars in the touristic areas.

The Ministry of Tourism in Jordan has indicated that the tourism strategy nowadays emphasizes the continuation of tourism products in Jordan and the continuation in promoting these products in the European Market particularly in Britain, France and Germany. Also emphasized is the continuation of attracting Arab tourists. Besides, Mr. Rifai mentioned that Jordan's Tourism Board is currently conducting a promotional campaign for attracting European tourist, although the cost is relatively high. The percentage of expenditure on tourism promotion in Jordan stands at $1 \%$ (or around JD 5 million), which is relatively low compared with Egypt ( $2 \%$ or $\$ 80$ million) (Refa'I: 2002).

\section{The Contribution of the Concurrent Research}

The research aims at identifying the real perceived image of European tourists to the Hashemite Kingdom of Jordan. What all tourism personnel ought to know is that initial tourism image is normally established through mass and electronic media; news, periodicals, journals, magazines and World Wide Web, books, talk programs, slide shows, interviews with well acknowledged personalities, feature promotional films, musical and cultural performance, as well as tourism exhibits together with various cultural festivals. One must remember that world of mouth is a very effective communication tool (nepalnews.com, 2002) The understanding of perceived image related to socio-demographic variables can be helpful in targeting specific group, improving a particular tourists groups' relative image, and tailoring promotion strategy to specific demographic segments. (www.qualitymanagement.com: 2002) The research is distinguished mainly because it endeavors to attain the following objectives and to expand the literature on the aspect of tourism promotion;

- Tourism in Jordan is a potential servicing industry. Unluckily it is not being fully utilized and not activated to generate more national income to the kingdom. The research tries to develop more awareness to the aspect of European visitor's image, which is a crucial area of generating worthwhile, never-ending revenue.

- It attempts to find out the minds of European tourists to acquire the information regarding their likes and dislikes of the country.

- To seek answers to major issues such as the popularity of various locations and the relationship between nationality and image if any.

- Barriers standing ahead of Jordanian promotion in Europe.

\section{International Studies}

Donald Lundberg (1976) defines tourists as temporary visitors staying at least 24 hours in a country visited, when the purpose of the journey can be classified under of the following headings: a) pleasure, recreation, holiday, health, study, religion and sport, b) business, family, mission, meetings. Excursion covers travelers staying less than 24 according to the UN definition. Knowing the image marketing efforts can be changed to sharpen the image or change it as deemed desirable. Image studies provide information as to how particular groups or markets actually feel about distinction information which can be compared to what the promoters think is true. If the area is viewed as a place for fun and frolic, promoters can aim their advertising at groups who want that kind of entertainment. (Lundberg, D. 1976) Luisa Andrea, J. Ennique Bigna and C. Cooper (2001) in their research entitled Projected and Perceived Image of Spain as a Tourist Destination for British Travelers", explained the relationship between the perceived and projected image of Spain in the British market. The projected image was obtained through an analysis of the principal sources of secondary information on the promotion of Spain while the perceived image was obtained from a study carried out among 120 British tourists. Evaluation of destination attributes and positioning of the Spanish touristics areas provided useful results of the perceived image. Some differences were noted between the projected and the perceived image of Spain. The paper concludes by recommending a eushmes- focused orientation in marketing strategies. Guests' perceptions and reactions to quality standards in the context of the provision of quality tourism services are must also be considered. The research findings show that European tourists place a high value on the human side of tourism. Laura Dargan (2002) in her research entitled "implications of the Internet for the tourism industry: An application to the Irish Tourism industry "she states that marketing's primary role in the tourism industry is to supply the consumer with the necessary information reservation and distribution facilities, there by stimulating and satisfying consumer demand. The role of marketing evolves with the changing dynamics of the industry and an analysis of same reveals numerous inadequacies in existing marketing practices".

Manual Baud-Bovy and Fred Lawson (1977) mentioned that the tourist image of a destination is of utmost 
importance in tourism development, a choice of destination is usually not made objectively but according to the image projected. Tourism images have to be: 1) as original as possible, 2) truthful, 3) capable of being implemented at a cost appropriate to their attractiveness. The tourist product, which is the concrete expression of tourists image, may be classified in three categories: resources at destination, facilities at destination, transport to destination. To create an attraction tourist image, tourist image should be as original as possible to give the resort a personality so that it could be easily remembered. This may be achieved in a number of ways by making the best use of the particular resources and the features and uniqueness of the site; adopting development plan and scale and design-building to reflect the character of the surroundings, as well as giving an imaginative treatment to the facilities, providing opportunities for contracts with local people craft and customs for introducing specific features to create atmospheric identity. The tourist image is the suitability for tourist planning for two essential characteristics: maximum attractiveness (the tourist product making the best of existing resource), and maximum practical capability.

Victor Middleton \& Jakie Clarke (2001) stress the importance of attitude of customers towards products strongly influencing their buying decisions. Destination images are not necessary grounded in experience or facts but they are always powerful motivators in leisure, travel and tourism. Images and the expectations of travel experiences are closely linked in prospective customers minds. In relation to the forms of tourism regulation, some essential rules do exist to regulate the various industries that make up the tourist industry. However, tourism industry in the USA is regulated at the level of the State and at the level of federal government and more than an authority is regulating the tourism activities particularly the air and ship travel. Forms of regulation in the tour industry can be directed towards two purposes: prevention and correction. (McIntosh \& Goelner: 1976:pp.459-471) Chon in his study entitled "Satisfaction and dissatisfaction for the consumers in Tourism and its relationship with the perceived image of the site", says the purpose of the work was to explore the relationship between the perceived image and the degree of satisfaction or dissatisfaction. Mainly the findings states that the satisfaction has a relationship with the tangible and symbolic benefits that are actually received. According to a study published by the WTO on competition in international tourism, tourism and travel industry are strongly globalized. There are still certain problems facing developed and developing countries regarding competition, essential facilities control and computer reservation system. To face such a competition in an effective manner, tourism authorities should have accurate market definition and market structure; hence, competition among nations to attract more foreign tourism should be taken into account when designing tourism campaign at a national level (WTO: 2001). Concerning the question of who bears responsibility for developing effective tourist promotional campaigns, the answer is that it is a common responsibility between the private and public sector. The recommendations were that a new type of cooperation should be in the framework of liberalization in trade of tourism services to include region-specific approaches among countries at the Mediterranean. Proposed competition laws, which can be applied to tourism activities, should be drafted. Besides, there has to be encouragement of better cooperation between local tourism's service suppliers and foreign operators aimed to achieve transparency in tourism production and channels (World Tourism Organization: 1999). Concerning the character of cultural tourism, tourism is an irreversible social, human, economic and cultural fact. Cultural tourism is that form of tourism that aims at discovery of monuments and sites (ICOMOS: 2002

\section{Summary of Previous Studies}

The total tourism products and services have a distinctive marketing approach. Being distinctive comes from the fact that, contrary to tangible or industrial marketing concept, services marketing is where the customer or guest has to come to the place of service provision and that the product is of intangible features in many of its characteristics. Consumer Travel Industry includes the travel product as a service produced and consumed at the same time. Consumer rights of travel, products and services have the same rise and protection as consumers of other products sold in the business area. While most legislation and regulation are created mainly for other industries and are quite broad, they have some applicability to travel industry. This is particularly true in the advertising area. The tourism package tour has grown in the last thirty years into a sizable industry. In the US alone, more than 18.7 million Americans bought package tours spending over $\$ 4$ billion Concerning tourists' satisfaction and dissatisfaction it is noted that the consumer dissatisfaction with product and services rises during period of economic recession; when incomes decline and prices rise, consumerism is least noticeable. As far as tourism complaints in the tourism industry are concerned they fall into four broad categories: failure to provide advertised items, lack of notification of change, omission of significant information, limitation of liabilities for changes. Tourists and tourism are effective contributors to the national economy, but in order to enhance tourism promotion, tools must be effectively used through the most popular media in each of the Europeans communities as per the demographic indicators of each state. According to F.Al Hammad Study, there is a relationship 
between the marketing mix: product, price, promotion, distribution, manpower, and the tourist 's satisfaction. According to the author, the Jordanian present tourism products which are found to be most attractive are:

- Archeological forts and castles. - Local communities festivals.

The author explained the widespread desire and curiosity among the European to experience the life and heritage of the natural habitat of Bedouin Arab. On a different aspect, he found that the religious sites of archeological significance were not high in demand. The key assumption of the effective image change depends on an assessment of the existing tourism images. Product image is seen as an abstract concept incorporating the influence of past promotion, reputation and peer evaluation of competing alternatives. It is necessary to train the personnel working in tourism promotion to create public awareness of the significance of attracting foreign tourism to the country (Al-Hamoud \& Armstrong, 1996). Concerning the issue of who bears the responsibility for developing effective tourist promotional campaigns, it is recommended that it is the responsibility of a partnership between the private and public sector. A new type of cooperation among the Mediterranean countries should be in the framework of liberalization and a proposed competitive law should be drafted to be imposed to supplier and consumer states. (World Tourism Organization Conference Memorandum: 1999). Gaining better understanding of how customers evaluate, select, use and occasionally abuse services should lie at the heart of strategies for designing and delivering the service product. Successful firms in providing high quality service are good at listening to their customer and their employees (C. Lovelock and L. weight 2002).

\section{The Importance of the Research}

The 'importance' of this research stems from the fact that the positive tourists image is significant for enabling the decision makers in tourism sector to improve and positively affect the crucial factors of tourism operations. Moreover, the researcher will explore the obstacles hindering the attraction of the European tourism to Jordan; the feedback of European tourists is necessary to develop the internal and external promotional tourism campaigns needed for developing the arrival of more European tourists to Jordan. In this field of study, there are very few researchers that tackled the problems of tourist image towards the tourism products in Jordan. International Tourism is becoming a booming servicing industry in various parts of today's world. Tourism is able to create new prospects, dimensions and jobs. Tourism has led to the economic revival of many declining sectors on a worldwide scale and has fostered the social and cultural integration by promoting friendly dialogue between visiting tourists and hosts. The importance of this papers lies in the fact that the tourism sector is a potential player in the Jordanian Economy and is expected to witness more consumers, income and job opportunity creation. In addition, the following major considerations should be taken into account as well:

First:- This paper is one of few that deal with the overall picture of European tourists. No early studies were found in the area of the real Perceived Image (Final, lasting and probably permanent- of his / her touring experience to the country; Jordan).

Second:- Tourism plays a growing vital role in enhancing the Jordanian national economy, on a global scale, the annual contribution of tourism exceeds $\$ 2,000$ billion and is considered the second largest source of revenues after the petroleum industry (Kotler, 2002). In highly developed nations people spend on tourism more than they spend on clothing and medical care.

Third:- A well-designed and carefully tailored-made tourism service marketing mix is an essential basic ingredient of the realistic, optimistic and promotional efforts of tourism for Jordan. A distinguished perceived image by the majority of the European guests will, undoubtedly, take a lot of collective coordination and dedicative work in both the public and private sectors.

However, this research will be a corner stone in studying this major issue in a more detailed manner.

Fourth:- It is of a great importance to find out the most popular places of interest to the European tourists, from different European demographic segments.

However, more analysis is needed to find out how we can best match between the places of popularity among the touring Europeans segments and the in-advance scheduled length of stay.

Fifth:- It is equally important to evaluate the quality of the provided tourism services as perceived by European tourists in particular. There have been very limited attempts to study this acute aspect on national or international scales.

Sixth:- Tourism experts should receive help to gain an understanding of the European tourist perception.

Seventh:-International tourism competition is unattainable unless tremendous efforts are exerted to provide quality services that exceed guest expectations. 


\section{Problem of the Research}

The 'research problem' is that the perceived image of the European tourists towards the tourism products in Jordan is vague and probably not known to most concerned authorities and decision-makers in Jordan. This study comes to shed light on this problem.

In the light of the rapid growth of universal tourism and declining demand of Jordanian tourism products, as can be seen in tables (1.1) and (1.2), involve such changes that force us to interrogate all available ways and means to elevate the current circumstances. The problem of the research is seeking mechanisms to initiate the positive essential framework, a pre-requisite for development of strategic and tactical plans for

\section{The Objectives of the Research}

The 'objectives' of this research are to highlight the real image of the European tourists towards Jordanian tourism products; to investigate the criteria used by the European tourists in their judgement on the tourism products in Jordan; and to rank the European tourists according to the perceived preview about the Jordanian tourism products.

The main objectives of the research can be summarized as follows:

To view the real perceived image by European tourists concept as a tool of rectification toward improving the quality of Jordanian tourism products.

To relate among European tourists socio-economic determinants dimensions (Nationality, Age, Gender, Marital status, Occupations, European tourists annual income and the perceived image scale).

To determine the popularity of tourism locations from the European tourists perspective.

\section{Research Hypotheses}

The 'hypotheses' of the research are that the perceived image of the European tourists of the Jordanian tourism products are not positive; there are differences among the perceived images of the European tourist groups towards the Jordanian tourism products; There are significant differences among the perceptions of the European tourists according to their nationality, age, gender and education.

The researcher has developed several hypotheses to be investigated and tested statistically in order to be accepted or rejected with the purpose of developing findings and conclusions. These hypotheses are:

1-The perceived image that the European tourists hold toward the Jordanian Tourism product is negative.

2-There is no significant relationship between the nationality of European tourists and the perceived image toward the Jordanian tourism product

3-There are no significant differences in the perception of European tourists toward the Jordanian tourism product attributed to Socio-economic determents (Nationality, Age, Gender, Education, Occupation, Marital Status and Tourist Annual Income Level) studied individually or collectively.

\section{Research Limitations and Determinants}

The researcher encountered some obstacles. Here are some:

The "limitation' of the study is that very few sources and references are available to the researcher on this topic; besides there is limited time available for the researcher to conduct more in-depth investigation of a larger sample of tourists and, finally, the lack of financial resources available for the researcher to enable him to travel to all tourist sites in Jordan to meet the European tourists listed in the convenient sample.

The subject data matter was not accurately categorized which caused difficulty in accurately determining the research population in order to acquire the most idealistic

\section{Research sample}

Despite all efforts, some public and government authorities could extend neither co-operation nor support to the researcher.

- The summer season of 2002 was very disappointing as far as tourism is concerned because of the political and military circumstances in the Middle East.

- Corporation was very scarce when it comes to having some details from Hotels or Touring Guides.

More detailed investigation is needed. To find out the important criteria used by various European segments in their judgement toward the tourism product of favorable features of products in various Europeans tourists segment must be acknowledged in future research. 


\section{Research Methodology}

Research Population:The target population of the study incorporate European tourists who visited Jordan during the period of June, July, August, September and October of Summer Season of 2002 (Sampling Units). The locations are scattered across the Kingdom; Hotels of Amman, Petra and Aqaba as well as Airports of Amman, Aqaba together with Jarash and Petra Archeological sites.

Samples of the Research: A convenient sample was selected by the researcher, and comprises 350 European tourists from all countries of the continent of Europe (Sample size). The sample was selected randomly as there was scarcity in the number of tourists, the threatening political circumstances surrounding the region, time limit and shortage of financial resources of the researcher. The questionnaire was distributed among 350 tourists during the period, received 291 responses, that is $83 \%$ return rate of total circulated papers (Sample size).

The researcher attempted to select those people who is an accurate representation the population as a whole (variation of the tourists groups): Different nationalities, age groups, gender, educational level, occupations, marital status and annual income.

Regarding the sample design the researcher used the statistical data found in table (1.1) that is 175,424 tourists and decided to select $\% 0.02$ of the figure which is calculated to be 351 of which actual response received were $29183 \%$ return rate. For the stated issue the consumption behaviour researches can not deny that the majority of studies in this research scope use a sample between 250-500 to defend their hypothesis.

Regarding the questionnaire testing the test of questionnaire was modified and changed three times before the final phase. At the initial stage an unofficial piloting structured interview was used to initially determine the types of questions most appropriate.

\section{Data Collection:}

This research depends on two types of data;

Primary data: Which are collected through the questionnaire that was prepared to measure the independent variables, intermediate variables and dependent variables. The data have been collected specifically for the purpose of the research from Jordan main airports, Jarash and Petra Arcological sites, four and five stars hotels, tourism and travel agents.

Secondary Data: This group of data was gathered from theoretical literature, books, references, professional periodicals, newspapers, Internet and other available media. This information forms the base for the research.

\section{Sampling Unit and Statistical Analysis}

For the purpose of this research the sampling unit is the randomly selected European tourist visiting Jordan during the summer season of 2002, the questionnaire was distributed to the available tourists who, by incident, happened to be touring the tourist sites and locations within the specified time period; June, July, August and September 2002. The following statistical techniques used in the analysis:

(a) Validity and Reliability:

1) Validity:

Literally this means the capability of the questionnaire to accurately measure the same way each time, the variables, "Best available approximation to the truth of falsifying a given inference proposition of conclusion" (Cork, 1979). Which the questionnaire is designed to measure, basically, the researcher depends on the faced validity.

A scattered group of Tourism and marketing experts were consulted for this respect and the statements were modified in accordance with their comments.

2) Reliability:

Cronbach's Alpha: Measurement device has been used to testify the tool stability; in this Research the result was $88 \%$, that is more Than adequate- level of $60 \%$ (Sekaran, 1984). To test the reliability and validity of the questionnaire, this device has been used.

Under the same subject; the author finds it necessary to state that "the design of the questionnaire will determine whether the data collected will be valid and reliable.

The researcher must be able to evaluate not only the questionnaire itself but also the specific wording of the questions. There are three steps to questionnaire design (a) The information (b) The questions types and wording (c) The visual layout and physical characteristics of the questionnaire. 
(b) Descriptive Statistical means/Measure:

The means used here are: (1) Arthmetical means, (2) Percentages, (3) Standard deviations (SD) and (4) Frequency as to describe the statistical data, obstacles encountering tourism development, and sites visited by the tourists

(c) One sample mean t-test; to evaluate the real perceived image of European tourists toward the Jordanian tourism products by comparing the mean estimate with standard mean=3. As an illustrative example, we (evidential proof) may state the scale responses for normal assessment are:

\begin{tabular}{|l|l|l|l|l|}
\hline Strongly agree & Agree & Undecided or Neutral & Disagree & Strongly Disagree \\
\hline 5 & 4 & 3 & 2 & 1 \\
\hline
\end{tabular}

Accordingly the mean of this assessment is:

EMBED Equation.3

If the $t$-calculated is more than $t$-tabulated, in this case we will reject the null hypothesis $(H o: U<3)$ and this type of testing is concerned with the first hypothesis of the research.

d) Two independent sample means (t-test)

This analysis is used to compare between mean of perceived image for males with the mean of the perceived image of females, to determine whether there is a significant difference that depends on t-calculated which will be compared with t-tabulated. If $\mathrm{t}$-calculated is more than $\mathrm{t}$-tabulated we will reject the null hypothesis. But if $\mathrm{t}$-calculated is less than t-tabulated, we will accept the null hypothesis. This particular case is applied to the third hypothesis.

e) Analysis of Variance (One Way Anova)

This analysis is used to test the effect of Tourists demographic features -Nationality, Age, Education, Occupations, Marital Status, Annual Income- and Real Perceived Image. If the result shows significant difference, then the researcher will use Scheffe test; this test is based on the principle of comparing two groups to determine which one is different. This is concerned with second hypothesis.

\section{European tourism flow toward Jordanian Tourism products:}

The research attempts to find answers to the following questions:-

1- What is the real perceived image concept from a national, European and international perspective?

2- What is the importance of a tourist's perceived image as a tool for rectification and enhancement of National tourism?

3- What is the impact of attaining a high positive level of Europeans' perceived image on the national tourism inflow to Jordan?

4- What are the obstacles and barriers hindering the inflow of European tourists to Jordan?

5- Are there any changes between the expected image (pre-tour projections) of Jordan and the real perceived image as obtained by the European tourists due to their departure (post-tour image)?

6- What are the least and most popular, features of Jordanian tourism products from various European tourists' perspective?

\section{Findings and conclusions}

\section{Findings}

The real perceived image of the majority of the European tourists is positive

There is a difference in the real perceived image among various nationalities.

The real perceived image was at its best and favorable term for Netherlanders nationals who stand in same footing as the Swedish. Both stand at 3.7917 mean.

In the second place, we have the German nationals with 3.6288 mean.

The Italian nationals, perspectives come at the third place with 3.5699 mean.

The Belgium group of citizens stand in the fourth place in their perspective with 3.4792 mean. 
The Austrian come in the fifth place with 3.4583 mean.

The Russians come in the sixth place with 3.375 mean.

The Denmark nationals come in the seventh place with 3.3565 mean.

Others and unclassified nationals come in the eighth place with 3.2774 mean.

The Spaniards come in the ninth class with 3.152 mean.

The French come tenth with 3.147 mean.

The British come eleventh with 2.9830 mean. This actually indicates a negative perspective toward the Jordanian tourism products.

There is a difference in the real perceived image among various age groups

The real perceived image was at its best. And most favorable among age groups of 50-59, with 3.6548 mean.

In the second place comes the age group up to 19 with 3.6534 mean.

In the third place comes the age group 35 to 49 with 3.4555 mean.

In the fourth place comes the age group 60+ with 3.45 mean.

In the fifth place comes the age group 20-34 with 3.0472 mean.

There is a difference in the real perceived image among various income groups level.

The real perceived image was at its best among "\$30.000-48.000 U.S earners", with 3.6603 mean.

The real perceived image was in the second place among the earners of "48.001 U.S and over", with 3.5271 mean.

In the third place come earners of less than \$6000US, with 3.4396 mean.

In the fourth place come earners of $\$ 6.001-\$ 16.000$ U.S level group with 3.333 mean.

In the last and fifth place come earners of \$10.001-30.000 U.S level group.

\section{Conclusions}

In general, the majority of European nationalities perspective have a positive image of Jordan; they all, except for the British, possess more than 3 mean average.

Among the European Groups who have the most favorable opinions are the Netherlanders and Swedish (highest in prospective). The Swiss, German and Italian who possess fair popularity toward Jordan. Midway popularity is found among Belgium and Austrian people.

Among the European groups who possess fair favorable opinions are the Russians and Danish.

The least favorable nations are others, Spanish and the French.

The British possess a negative perspective toward tourist products of Jordan.

Concerning the perceived image among different age group the conclusions are as follow:

Regarding the age groups who have positive perceived image, the age range groups 0-19 and $50-59$. Less positive prospective came from age range group 35-49

Among the age groups who have the least positive perceived image, groups 20-34 and 60+.

The European female tourists have a fairy less than average mean 3.25 than the males of 3.437 average mean.

\section{Educational level}

Among the educational level groups who favorably have positive perceived image, the age group "Below secondary school ert" and secondary school levels, is first.

Less positive perspective comes from "Bachelor degree" level group.

Among the educational level groups who possess the least positive perceived image, the groups of "post graduate" and "high graduate diploma" levels.

Occupations/Professions

Among the occupational groups who favorably have positive perceived image perspective "Student, Housewife's, Others" and "Government servant" groups, rank first.

Less positive perspective is received from professional M.D, lawyer, etc. 
Among the occupational groups who possess the least positive perceived image, "lecture, teacher, etc" and "Business man, trader, etc", come last.

\section{Martial Status}

There is a difference in the perceived image among the various martial status groups.

"Separated marital status" and "divorced martial status" groups both have favorable positive perceived image prospective.

Less positive perceived image is received from "Married with no children" group.

"Single marital status" and "Married with children" groups possess the least favorable opinions.

\section{Income Levels}

The income levels groups who favorably have positive perceived images are the earners of "\$30.000-48.000 US" and 48.000 and over

Less positive perspective is received from earners of "less than \$6000 US"

The income levels earners who possess the least positive perceived images are the earners of \$6001-16.000 US group and $\$ 16001-30.000$ US group.

\section{Specific Recommendations}

\section{(Basically related to conclusions)}

An organized opinion poll and questionnaire survey must be specifically designed and provided to British tourists in order to find out their precise prospective toward of the Jordanian tourism product, and services on average, the British group got less than 3 mean in the response to the questionnaire (because it is very essential to know what they desire and wish to see) in Jordan.

All the results and findings of the above step should be implemented only if they are possible - to the convenience of other tourists groups plus available amenities and facilities.

To a leaser extent, the same steps - as above - may be applied to the peoples of Denmark, Spain, France, and other groups of unmentioned nations and Russia.

Maintaining the decent standard must be kept with other nationalities groups i.e, Netherlands and Sweden who have a decent profile of Jordan.

A questionnaire survey and organized opinion poll must be mainly designed to the tourists age group of 60 years old and more and for those of 20 - 34 age group.

It is very essential to know what they desire and wish to see or have while in Jordan.

Another detailed questionnaire must be applied to tourists of age group 35-49

The Authorized personnel must keep up the good level of perceived image among the groups of 50-59 and 0-19 through ascertains of the good rendered services given to them.

Concerning the educational level we may apply the same ideas as in point 5 above to highly educated individuals i.e "Post graduate" and "high graduate diploma" holder groups.

Another survey must be designed, circulated and collected to find out the particulars that are of high concern to the European tourists' who posses 'Bachelor degree' level. When all assured information is gathered, services must be provided accordingly.

Upkeeping and maintaining the decent standard must be kept with Age groups 'Below secondary school certificate' and 'secondary school certificate' levels.

Concerning the females group of the European holiday makers to Jordan, they must be given the chance to express their precise opinions regarding the Jordanian tourism products. The said information can either be verbal or in written form in answering the questionnaire. The Jordanian products/services providers must ensure that the products suit the Europeans and up to their expectations.

Jordan must upkeep the products and services quality as desired by both groups, namely 'Student, house wives and others' and 'government servants'.

A detailed questionnaire must be used for occupational group of M.D, lawyer etc, and assured collected information must be used to rectify the services to suit the group provided it does not contradict with the comfort of the other groups. 
A rigid survey must be designed, and circulated to the groups of last positive perceived image, "lecture, teacher.. etc and Business man, trater etc.."

Jordan must upkeep the products and services quality as desired by both the separated and divorced martial status groups.

A detailed questionnaire must be planned for married with no children to improve their perceived image.

For both, "Single" and "Married with children" groups a precise and rigid survey must be designed, and circulated to member of such groups. The resultant information must be carefully researched and, if possible, be applied to the other groups.

Jordan must maintain the perceived image the European tourists of annual income level earners of $\$ 30,000-48,000$ US and $\$ 48,000$ US and efforts must be enhanced to continue the perceived image standard for both groups.

A questionnaire must be designed and circulated for the European tourists' earning group of less than \$6000US if feasible, to develop their perceived image and to put their comments into reality provided no harm is caused to other groups.

A Rigid survey must be planned and circulated to group of \$6001-16.000US and \$16.001-30.000US annual income earners. Responses must be analyzed, and the resultant information must be implemented without negative impact to other group.

\section{Suggestions}

A committee composed of the Ministry of Tourism \& Antiquities and Jordan Tourism Board and selected members of the private sector must be set up to supervise all issues relating to tourism trade in Jordan.

The proposed committee list of activities may include, but not limited to the following obligation duties:-

The formation of inspection teams to oversee the rates and prices.

Selecting the most appropriate plans and schemes to promote the country abroad

Advise the authorized personnel within the governmental circles of the financial, budgeting allocation requirements.

Collect information related to the different European nationalities in terms of demographic, social and other characteristics to initiate the tourism data bank.

Jordan must seek technical assistance and support from WTO (World Tourism Organization) to improve the quality and standard of tourism services and develop national human capabilities.

A well-trained and reasonably informed police force must be employed to avoid the unethical, misconduct behavior against the European tourists, as well as tourists from other parts of the world.

Medical Hospitalization tourism is a potential tourism revenue, which must be reorganized to suit the possible users. Monopoly in this respect must be discovered and treated to the national cause.

Regional and urban committees may be formed in different major districts of Jordan to oversee the tourism aspects in that area. The regional committee may be headed by a well-acknowledged and educated individual, while the duties of the committee may incorporate issues such as: Amending, protecting and rectification of tourists areas, Human resources recruitments for the purpose, control over the financial revenue and expenditure.

The government must provide a decent budget allocation for the tourism sector. The sum to be considered must be in proportion to the actual tourism annual income, taking into account that tourism provides $9 \%$ of the national Jordanian income.

Already imposed taxes must be reconsidered in the light of surrounding competitive countries.

Major and significant archeological sites must be supplied with all vital services: spare electrical generators, and access to medial care units and civil defense force facilities.

Medical Hospitalization tourism is a potential tourism revenue which must be reorganized to suit the possible users. Monopoly in this respect must be discovered and treated to the national cause.

Regional and urban committees may be formed in different major districts of Jordan to oversee the tourism aspects in that area. The regional committee may be headed by a well - acknowledged and educated individual, while the duties of the committee may incorporate issues as: Amending, protecting and rectification of tourists areas, human resources recruitment's for the purpose, control over the financial revenue and expenditure. 


\section{Proposals for New Studies}

The correlation between the actual features and characteristics of the Arab, Jordanian individual i.e. his/her hospitality gesture and the possibility of expanding the tourism boom must form the title of a new study which may shed some light on how the public authority may use our natural resemblance to promote its services.

Carefully designed questionnaires must be established to acquire in- depth data relevant to the precise needs of the tourists. The questionnaires must be circulated on regular, timely basis and the outcomes must be monitored carefully. All these will lead to build up a comprehensive Tourism data bank that can help in creating suitable tour packages capable of promoting the country and attracting holidaymakers from different corners of the world.

\section{References}

A.Alak. Basheer \& H. Tae'e. (2002). Perceived Quality of Services Provided by Hotels In Jordan Among Foreign Units (A Field Study).

Abu Rabah \& Abdelrahman. (1987). Arab Tourism: Policy and Strategy. Al Dustor Commercial Publishing House. Amman.

Al-Domur \& Hani Hamid. (2002). Service Marketing, Dar Wael Publishing Co. Amman (In Arabic).

Al-Hamed \& Fawaz. (2000). The Factors Determining The Tourism In Jordan'S Badia, Ma Thesis At The University of Jordan/ Faculty of Business Administration. Amman (In Arabic).

Al-Humoud, Abdullah \& Edward Armstrong. (1996). Image of Tourism Attraction In Kuwait. Journal of Travel Research, Spring, Vol 34. Issue 4 P.76.

Al-Shora \& Mohamed Salim. (2001). Market Segmentation In The Tourist Service Sector In Jordan. Journal of Research of The University of Applied Sciences, Vol, 4 No. 6.

Baud - Bovy Manuel \& Fred Lawson. (1977). Tourism and Recreation Development. Cby Publishing Co. Boston.

Central Bank of Jordan, (1999). Monthly Statistical Bulletin 1999, Amman.

Icomos. (2002). Charter of Cultural Tourism. Www. Isomos. Org/ Tourism.

International Institute for Environment and Development. (2001). Pro- Poor Tourism: Harnessing The World'S Largest Industry For The World'S Poor. Johannesburg, South Africa.

Ita Office Of Travel \& Tourism Industry. (1998). Tourism Role in A Changing Economy, Geneva.

Lundburg Donald E. (1976). The Tourist Business. 3rd Edition, Congress Library. Washington, Usa.

Mcintos Robert \& Goeldner Charles. (1984). Tourism Practices Philosophies, Fourth Edition, John Wily and Sons. New York.

Middleton, Victor \& Jackie Clark. (2001). Marketing In Travel and Tourism, Butterworth, Oxford.

Middleton, Victor T. (2001). Marketing In Travel and Tourism. Butterworth Publishing Co. Oxford.

Ministry of Tourism. (1999). Employment in Tourist Activities in Jordan During Selected Years Of 1993, 1996, And 1999. Amman.

New Jordan Economic Center. (1999). Jordan Tourism Strategy for Next Century, A Symposium Conducted Aqel Baltaji and Other. Amman.

Rifa'I Talib. (2002). Tourism Economics of Jordan, Symposium At Banking Society In Jordan, On 29th of July.

Royal Scientific Society. (1997). Tourism Sector in Jordan: Realities and Expectation. Part 1 And 2. Amman.

Royal Scientific Society. (2000). Tourism Economics in Jordan, Amman.

Royal Scientific Society. (2000). Tourism Economics in Jordan: Essential Facilities and Marketing. Amman.

Sustainable Tourism According Unep. (2001). What Is Sustainable Tourism. Nairobi, Kenya.

Tourism Development Authority. (1989). Jordan Tourism Directory, Amman. 
Table 1. The Main Indicators of Tourism Sector in Jordan (during the period 1997-2001)

\begin{tabular}{|c|c|c|c|c|c|c|c|c|c|c|c|}
\hline $\begin{array}{l}\text { Indi- } \\
\text { cators }\end{array}$ & $\begin{array}{l}\text { Arrivals in } \\
\text { thousands }\end{array}$ & $\begin{array}{l}\text { Total } \\
\text { tourism } \\
\text { income } \\
\text { /GDP }\end{array}$ & $\begin{array}{l}\text { Value } \\
\text { Added } \\
\text { in } \\
\text { Million } \\
\text { JD } \\
\text { (current } \\
\text { prices) }\end{array}$ & $\begin{array}{l}\text { Value } \\
\text { added } \\
\text { /GDP } \\
\text { (constant } \\
\text { prices) }\end{array}$ & $\begin{array}{l}\text { Credit } \\
\text { facilities } \\
\text { provided } \\
\text { to } \\
\text { tourism } \\
\text { sector in } \\
\text { million } \\
\text { JD }\end{array}$ & $\begin{array}{l}\text { Credit } \\
\text { Facilitie } \\
\text { provided } \\
\text { to } \\
\text { Tourism } \\
\text { sector } \\
\text { from } \\
\text { IDB } \\
\text { in } \\
\text { Million } \\
\text { JD* }\end{array}$ & $\begin{array}{l}\text { Number } \\
\text { of } \\
\text { Hotels }\end{array}$ & $\begin{array}{l}\text { Number } \\
\text { of } \\
\text { Rooms }\end{array}$ & $\begin{array}{l}\text { Room } \\
\text { Occupancy } \\
\text { Rate }\end{array}$ & $\begin{array}{l}\text { Number } \\
\text { of } \\
\text { employ- } \\
\text { yees } \\
\text { in Hotels }\end{array}$ & $\begin{array}{l}\text { Employ- } \\
\text { ment } \\
\text { in the } \\
\text { Tourism } \\
\text { sector }\end{array}$ \\
\hline 1997 & $4,266,2$ & $12.3 \%$ & 256.8 & $5.8 \%$ & 70 & 29.6 & 336 & 12109 & 43.6 & 7815 & 16438 \\
\hline 1998 & $4,586.0$ & $11.6 \%$ & 259.4 & $5.5 \%$ & 108.7 & 39.4 & 380 & 13704 & $37.9 \%$ & 8510 & 17550 \\
\hline 1999 & $4,767.5$ & $11.6 \%$ & 279.6 & $5.8 \%$ & 140.5 & 43.4 & 422 & 16181 & $34.9 \%$ & 9378 & 20569 \\
\hline 2000 & $4,618.1$ & $9.9 \%$ & 266.4 & $5.1 \%$ & 155.2 & 32.5 & 452 & 17485 & $39.5 \%$ & 9785 & 21515 \\
\hline 2001 & $5,235.0$ & $9.1 \%$ & 265.4 & $4.9 \%$ & 171.0 & 33.5 & 472 & 19247 & $30.5 \%$ & 11446 & 22864 \\
\hline
\end{tabular}

*IDP=Industrial Development Bank

Source: Central Bank of Jordan (2000) Annual Report of 2000, Amman 